\title{
Genetic Structure of Populations of Specially Protected Mollusk Cepaea vindobonensis (Mollusca, Gastropoda, Pulmonata) in the Northeastern Part of the Modern-Day Range
}

\author{
E. A. Snegin ${ }^{a, *}$ and E. A. Snegina ${ }^{a, * *}$ \\ ${ }^{a}$ Belgorod National Research University, Belgorod, 308015 Russia \\ *e-mail: snegin@bsu.edu.ru \\ **e-mail: snegina@bsu.edu.ru \\ Received August 4, 2016; in final form, October 7, 2016
}

\begin{abstract}
A research study on the population structure of relict and specially protected species Cepaea vindobonensis Fer. (Mollusca, Gastropoda, Pulmonata) in the conditions of the northeastern part of the modern-day distribution range is conducted with the use of allozymes and DNA markers. Groups with both high and low levels of genetic diversity are revealed. A high degree of differentiation in the studied populations $\left(F_{\mathrm{st}}=0.231, G_{\mathrm{st}}=0.265, \Phi_{\mathrm{st}}=0.261-0.263, N_{m}=0.630-0.832\right)$ is noted, which indicates a disruption of migratory channels and prolonged isolation from each other. Calculation of the effective population size and its comparison to analogous indices for background and vulnerable species of terrestrial mollusks demonstrate a high level of viability of the $C$. vindobonensis population within the studied area.
\end{abstract}

Keywords: terrestrial mollusk, allozymes, DNA markers, population structure, effective population size DOI: $10.1134 / \mathrm{S} 2079059718020090$

\section{INTRODUCTION}

The creation and management of the Red Lists of plants and animals has become an important aspect of work on preserving the living environment. Moreover, in the past few decades, this work has increasingly focused on monitoring regional systems, since the features of urbanization and the resulting ecological problems are specific to different landscapes. It is well known that the disappearance of a species begins with the disappearance of its population, as a result the distribution range is considerably reduced, genetic diversity decreases, and therefore loss of stability and extinction occur. In this case as a rule, the groups located at the borders of species ranges or some isolated territories suffer first, since during the distribution they inherited a small part of the species gene pool due to the gene flow. Moreover, loss of a portion of alleles is occasionally not replenished by the appearance of new genetic factors in the course of the mutational process. Caught in conditions of anthropogenic pressure, such populations are more vulnerable than other species of the community due to not having a genetic reserve of strength. It frequently occurs that a species included in the protection lists of separate regions is widespread in general and reaches large numbers within individual parts of the range; therefore, it does not need protection. However, this apparently flourishing state can change into a depressive state in a number of cases. In the normally varying environment, this extinction of the local peripheral groups is easily compensated by the influx of individuals from the central regions. At present, however, this maintenance of species stability is proving to be less and less feasible due to the destruction of biological corridors. By itself, the rare occurrence of a species in a region can only be an indirect argument, since it can be caused by the random drift of individuals from the adjacent satisfactory parts of the distribution range and can be considered an attempt at inhabiting new territories. Another version appears when the matter concerns native relict populations. Besides traditional demographic characteristics, profound knowledge of the state of the population gene pools is necessary to evaluate their viability, including the estimation of allelic and genotypic diversity, the degree of mutagenic pressure, and adaptive rearrangements at the genetic level. This information should become a serious argument in decision-making.

One such vulnerable species is the relict terrestrial gastropods, Cepaea vindobonensis Fer. ${ }^{1}$ (Austrian snail), known from the Pleistocene deposits of Europe. Its contemporary distribution range covers Southeastern Europe, Crimea, and North Caucasus [1]. Our studies were conducted mainly on the southern macroslope of

\footnotetext{
${ }^{1}$ In a number of studies on molecular taxonomy, this species is included in the genus Caucasotachea $[16,17]$.
} 
Table 1. Collection points of $C$. vindobonensis

\begin{tabular}{|c|c|c|c|}
\hline No. & Point & Point description & Coordinates \\
\hline 1 & Golovchino & Vorskla River valley near Golovchino village, highland oak forest & $\begin{array}{l}50^{\circ} 33^{\prime} 57.29^{\prime \prime} \mathrm{N} \\
35^{\circ} 48^{\prime} 12.29^{\prime \prime} \mathrm{E}\end{array}$ \\
\hline 2 & Khotmyzhsk & Vorskla River valley, floodland meadow near Khotmyzhsk village & $\begin{array}{l}50^{\circ} 35^{\prime} 05.99^{\prime \prime} \mathrm{N} \\
35^{\circ} 52^{\prime} 24.83^{\prime \prime} \mathrm{E}\end{array}$ \\
\hline 3 & $\begin{array}{l}\text { Bekaryukovskii } \\
\text { Bor }\end{array}$ & $\begin{array}{l}\text { Bekaryukovskii Bor Nature Monument, floodland of Nezhegol' River } \\
\text { (Shebekinskii region) }\end{array}$ & $\begin{array}{l}50^{\circ} 25^{\prime} 43.87^{\prime \prime} \mathrm{N} \\
37^{\circ} 04^{\prime} 12.07^{\prime \prime} \mathrm{E}\end{array}$ \\
\hline 4 & Valyiki & $\begin{array}{l}\text { Valyi River valley, bottom of chalk cliff, neighborhood of the city of Valu- } \\
\text { iki, near the road }\end{array}$ & $\begin{array}{l}50^{\circ} 13^{\prime} 24.38^{\prime \prime} \mathrm{N} \\
38^{\circ} 00^{\prime} 34.61^{\prime \prime} \mathrm{E}\end{array}$ \\
\hline 5 & Rzhevka & $\begin{array}{l}\text { Chalk cliff of west exposure in the floodland of Korocha River near } \\
\text { Rzhevka village }\end{array}$ & $\begin{array}{l}50^{\circ} 26^{\prime} 32.63^{\prime \prime} \mathrm{N} \\
36^{\circ} 58^{\prime} 22.89^{\prime \prime} \mathrm{E}\end{array}$ \\
\hline 6 & Kupyansk & $\begin{array}{l}\text { Floodland meadow of Oskol River valley, near the city of Kupyansk } \\
\text { (Ukraine) }\end{array}$ & $\begin{array}{l}49^{\circ} 42^{\prime} 37.60^{\prime \prime} \mathrm{N} \\
37^{\circ} 37^{\prime} 26.18^{\prime \prime} \mathrm{E}\end{array}$ \\
\hline 7 & Zhitomir & $\begin{array}{l}\text { Floodland of Teterev River, city of Zhitomir (Ukraine). Willow and maple } \\
\text { thicket }\end{array}$ & $\begin{array}{l}50^{\circ} 14^{\prime} 31.06^{\prime \prime} \mathrm{N} \\
28^{\circ} 40^{\prime} 23.52^{\prime \prime} \mathrm{E}\end{array}$ \\
\hline 8 & Khortitsa & Khortitsa Island on Dnepr River. Vicinity of city of Zaporozhie (Ukraine) & $\begin{array}{l}47^{\circ} 50^{\prime} 31.45^{\prime \prime} \mathrm{N} \\
35^{\circ} 04^{\prime} 10.03^{\prime \prime} \mathrm{E}\end{array}$ \\
\hline 9 & Dubki & $\begin{array}{l}\text { Dubki Park in vicinity of city of Nikolaev (Ukraine). Young oaks. Patches } \\
\text { of bush thicket are present. Is subjected to relatively intense anthropogenic } \\
\text { influence. Forest fires are frequent }\end{array}$ & $\begin{array}{l}46^{\circ} 58^{\prime} 42.47^{\prime \prime} \mathrm{N} \\
32^{\circ} 03^{\prime} 51.29^{\prime \prime} \mathrm{E}\end{array}$ \\
\hline 10 & STP & $\begin{array}{l}\text { City of Nikolaev. Park near South Turbine Plant. Mainly composed } \\
\text { of oaklets. Bush thickets are present in some places. It is subjected } \\
\text { to relatively intense anthropogenic influence }\end{array}$ & $\begin{array}{l}46^{\circ} 56^{\prime} 26.17^{\prime \prime} \mathrm{N} \\
32^{\circ} 03^{\prime} 03.45^{\prime \prime} \mathrm{E}\end{array}$ \\
\hline 11 & Penza & $\begin{array}{l}\text { City of Penza (Arbekovo district). Abandoned swamped area. Bush, } \\
\text { remains of an orchard, birch and ash tree plantings }\end{array}$ & $\begin{array}{l}44^{\circ} 56^{\prime} 32.53^{\prime \prime} \mathrm{N} \\
53^{\circ} 13^{\prime} 30.05^{\prime \prime} \mathrm{E}\end{array}$ \\
\hline
\end{tabular}

the Mid-Russian Upland (Belgorod and Kharkov regions), where the northeastern boundary of the natural distribution range of this species lies. In this area, the snails inhabit the relict communities of the preglacial and postglacial periods, such as the chalky pine forests and highland oak forests; they are also encountered on the dry, thoroughly warm slopes, chalky outcrops, and dry meadows [2]. The species is in the Red List of Belgorod Region [3].

There are a number of studies on the population structure of this species, which include the shell features and which cover the central and western parts of the distribution range of the species [4-13]. The aforementioned publications list the data on the correlation between the metric and coloration features of the shell of this mollusk and the microclimatic conditions of the natural and urbanized environment. Furthermore, one continuous population of $C$. vindobonensis, inhabiting the environment of the city of Nikolaev in southern Ukraine, was studied using molecular DNA markers $(R A P D)$ [14]. In our previous studies, we obtained the preliminary data on the population structure of $C$. vindobonensis in the Southern MidRussian Upland, obtained using the conchological features and allozymes [15].
The goal of this study was to estimate the state of the $C$. vindobonensis population's gene pools in the northeastern part of the distribution range for conservational purposes, based on the selectively significant loci of isozymes and neutral DNA markers (RAPD, ISSR).

\section{MATERIALS AND METHODS}

The tissue samples of $C$. vindobonensis specimens stored in a cryobank created in the Population genetics and Genotoxicology Scientific and Research Laboratory of Belgorod National Research University served as the material for this study. The sets of specimens from $C$. vindobonensis populations were collected during an expedition from 2006 to 2010 from six points in the Southern Mid-Russian Upland. We used the datasets from the western part of the species distribution range (points 7 to 10 ) and an adventive group from the city of Penza (point 11) for the comparison (Table 1, Fig. 1). In total, 999 specimens were studied for allozymes and 488 specimens were studied using DNA markers.

The allozymes were extracted from the feet of mollusks by freezing at $-80^{\circ} \mathrm{C}$ with the subsequent thawing and mechanical fragmentation in a $0.05 \mathrm{M}$ Tris- 


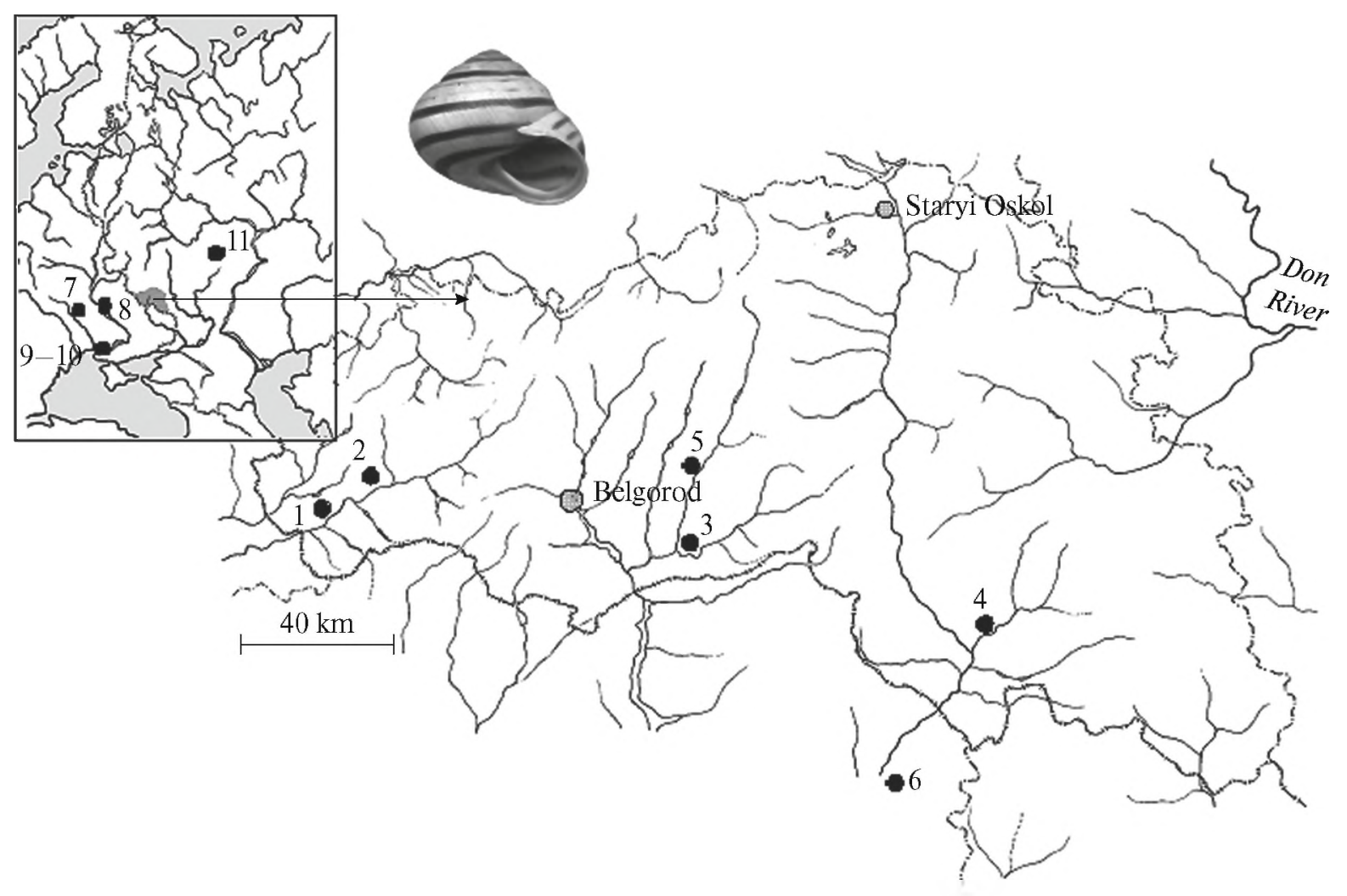

Fig. 1. Collection points of C. vindobonensis.

HCL buffer ( $\mathrm{pH}$ 6.7). The electrophoresis of isozymes was conducted in a $10 \%$ polyacrylamide gel in a VE-3 chamber (Helicon, Russia); a Tris- $\mathrm{HCl}$ gel buffer (concentrating gel at $\mathrm{pH} 6.7$ and separating gel at $\mathrm{pH} 8.9$ ); an electrode Tris-glycine buffer ( $\mathrm{pH} 8.3$ ). To detect nonspecific esterases, the blocks were stained in a substrate mixture of Tris- $\mathrm{HCl}(\mathrm{pH} 7.4), \alpha$-naphtyl acetate, and fast red TR. Three loci of nonspecific esterases were used as the genetic markers: EST1, a dimer with two alleles; EST2, a dimer with two alleles; and EST8, a monomer with three alleles [15].

We analyzed the variability of the DNA markers using Random amplified polymorphic DNA (RAPD) [18] and Inter simple sequence repeats (ISSR) [19] PCR methods. Two primers were used for the analysis: OPA10 (5'-GTGATCGCAG-3'; RAPD method) and $S A S 3$ (5'-GAGGAGGAGGAGGC-3', ISSR method). Amplification was conducted in a MyCycler thermocycler (Bio-Rad, United States). The reaction was carried out in $20 \mu \mathrm{L}$ of the mixture, which contained $20 \mathrm{ng}$ of genomic DNA, a PCR buffer $(10 \mathrm{mM}$ of Tris $\mathrm{HCl}(\mathrm{pH} 8.3$ ), $50 \mathrm{mM} \mathrm{KCl}, 2 \mathrm{mM} \mathrm{MgCl}$ ), $0.25 \mathrm{mM}$ $\mathrm{dNTP}, 0.5 \mu \mathrm{M}$ of the primer, and 1 unit of Taq DNA polymerase (inhibited for a hot start). The reaction was conducted under the following conditions: hot start, 2 min at $94^{\circ} \mathrm{C}, 35$ cycles (denaturion, $45 \mathrm{~s}$ at $94^{\circ} \mathrm{C}$; primer annealing, $15 \mathrm{~s}$ at $T^{\circ} \mathrm{C}$; synthesis, $1 \mathrm{~min}$ at $72^{\circ} \mathrm{C}$ ), additional synthesis, $10 \mathrm{~min}$ at $72^{\circ} \mathrm{C}$. The annealing temperature $T$ for the $O P A 10$ primer was $36^{\circ} \mathrm{C}$, for $S A S 3, T$ was $55^{\circ} \mathrm{C}$. The PCR products were separated by electrophoresis in $2 \%$ agarose gel using a TAE buffer (cooled to $+4^{\circ} \mathrm{C}$ ), $10 \mathrm{~V} / \mathrm{cm}, 45 \mathrm{~min}$. The blocks were stained with ethidium bromide.

Based on the pictures of the amplified fragments obtained by electrophoresis, we comprised the binary matrices, where the presence of a band was designated as 1 (allele $p$ ) and the absence was designated as 0 (allele $q$ ). Since nonspecific amplification products can occur in the RAPD method, we used clearly visible and reproducible amplicons for the analysis. The criterion of reproducibility was the repeated presence of amplicons after PCR for the same studied specimens. We isolated 17 loci using the OPA1O primer and 18 loci using the $S A S 3$ primer. The resulting DNA patterns and their interpretation are given in Fig. 2.

The obtained data were processed using the GenAlExv.6.5 [20], POPGENE32 [21], and MEGA6 [22] software.

\section{RESULTS}

The first stage of our studies was to estimate the degree of genetic heterogeneity of the studied $C$. vindobonensis populations. The allele frequencies and indices of genetic variability based on the utilized allo- 


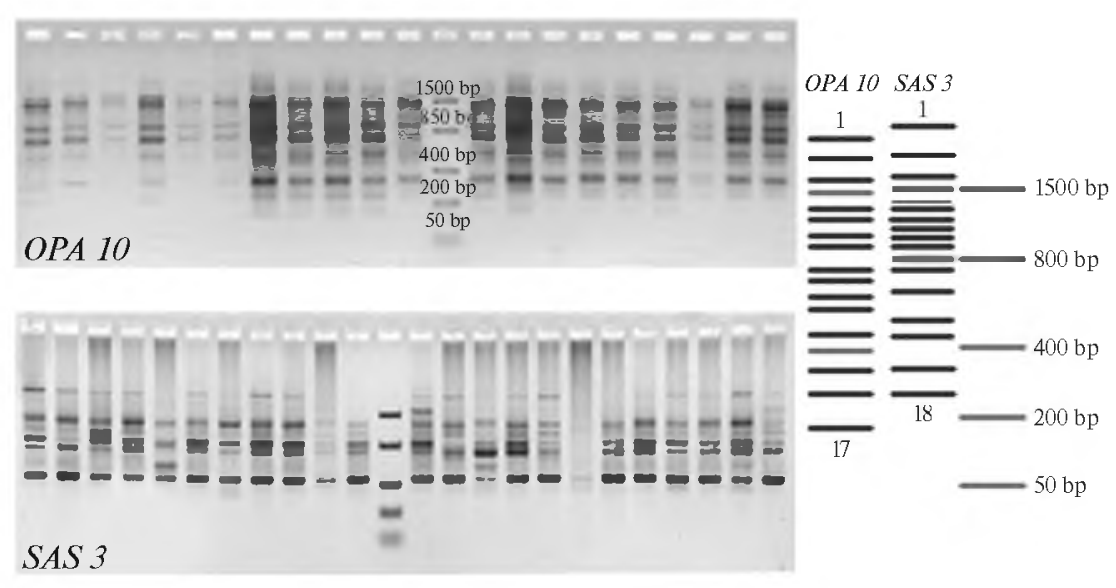

Fig. 2. RAPD and ISSR DNA patterns of $C$. vindobonensis.

zyme loci are listed in Tables 2 and 3, and on the DNA markers in Table 4.

Since we used limited datasets that included only a small portion of the population's allele pool to estimate the state of the population's gene pools of $C$. vindobonensis, the total number of multilocus genotypes $\left(N_{\mathrm{MLG}}\right)$ and the number of unique multilocus genotypes $\left(N_{\mathrm{MLG}-1}\right)$, i.e., the combinations that were only registered in a single dataset, were estimated in each group. The potential genetic diversity expected if a dataset size was increased ad infinitum $\left(N_{\max }\right)$ was subsequently calculated for each population based on the frequency distribution of the multilocus genotypes.
The analysis was performed using two nonparametric methods: Chao 1-bc (bias-corrected form for Chao1) [23] and the 1st order jackknife method [24]. All the calculations were conducted in SPADE [25]. The results of the analysis of multilocus genotypes are listed in Table 5.

The next stage of our study was to assess the degree of subdivision of the $C$. vindobonensis populations in the studied territories. To describe the genetic differentiation of populations based on allozymes at different levels of the hierarchical structure, we used S. Wright's model [26] (Table 6). Furthermore, the level of dissociation of populations was calculated based on M. Nei's

Table 2. Frequencies of alleles and indicators of genetic variability of allozyme loci in populations of Cepaea vindobonensis

\begin{tabular}{c|c|c|c|c|c|c|c|c|c|c|c|c}
\hline \multirow{2}{*}{ Locus } & \multirow{2}{*}{ Allele } & \multicolumn{10}{|c}{ Populations } \\
\cline { 3 - 12 } & & 1 & 2 & 3 & 4 & 5 & 6 & 7 & 8 & 9 & 10 & 11 \\
\hline \multirow{5}{*}{ EST2 } & 1 & 0.141 & 0.028 & 0.068 & 0.260 & 0.038 & 0.132 & 0.310 & 0.071 & 0.064 & 0.000 & 0.200 \\
& 2 & 0.859 & 0.972 & 0.932 & 0.740 & 0.962 & 0.868 & 0.690 & 0.929 & 0.936 & 1.000 & 0.800 \\
& $H_{\mathrm{O}}$ & 0.196 & 0.037 & 0.113 & 0.247 & 0.077 & 0.242 & 0.494 & 0.143 & 0.128 & 0.000 & 0.350 \\
& $H_{\mathrm{e}}$ & 0.243 & 0.054 & 0.127 & 0.385 & 0.074 & 0.229 & 0.428 & 0.133 & 0.120 & 0.000 & 0.320 \\
& $F$ & 0.194 & 0.314 & 0.106 & -0.358 & 0.040 & -0.059 & -0.154 & -0.077 & -0.068 & - & -0.094 \\
\hline \multirow{5}{*}{ EST3 } & 1 & 0.891 & 0.949 & 0.968 & 0.990 & 0.256 & 0.913 & 0.684 & 0.929 & 0.974 & 0.840 & 0.875 \\
& 2 & 0.109 & 0.051 & 0.032 & 0.010 & 0.744 & 0.087 & 0.316 & 0.071 & 0.026 & 0.160 & 0.125 \\
& $H_{\mathrm{O}}$ & 0.217 & 0.102 & 0.064 & 0.019 & 0.359 & 0.163 & 0.354 & 0.143 & 0.051 & 0.320 & 0.250 \\
& $H_{\mathrm{e}}$ & 0.194 & 0.097 & 0.062 & 0.019 & 0.381 & 0.159 & 0.433 & 0.133 & 0.050 & 0.269 & 0.219 \\
& $F$ & -0.122 & -0.054 & -0.033 & -0.010 & 0.059 & -0.029 & 0.181 & -0.077 & -0.026 & -0.190 & -0.143 \\
\hline \multirow{5}{*}{ EST8 } & 1 & 0.141 & 0.005 & 0.085 & 0.003 & 0.000 & 0.089 & 0.013 & 0.000 & 0.103 & 0.100 & 0.763 \\
& 2 & 0.152 & 0.102 & 0.058 & 0.208 & 0.000 & 0.200 & 0.108 & 0.000 & 0.154 & 0.120 & 0.238 \\
& 3 & 0.707 & 0.894 & 0.857 & 0.789 & 1.000 & 0.711 & 0.880 & 1.000 & 0.744 & 0.780 & 0.000 \\
& $H_{\mathrm{O}}$ & 0.370 & 0.176 & 0.185 & 0.026 & 0.000 & 0.379 & 0.177 & 0.000 & 0.282 & 0.400 & 0.225 \\
& $H_{\mathrm{e}}$ & 0.458 & 0.191 & 0.256 & 0.334 & 0.000 & 0.447 & 0.214 & 0.000 & 0.413 & 0.367 & 0.362 \\
& $F$ & 0.193 & 0.080 & 0.277 & 0.922 & - & 0.153 & 0.173 & - & 0.317 & -0.089 & 0.379 \\
\hline
\end{tabular}


Table 3. Parameters of genetic diversity in populations of $C$. vindobonensis derived from allozyme analysis

\begin{tabular}{c|r|r|r|r|c|c|c|c|c|c}
\hline Point & \multicolumn{1}{|c|}{$N$} & \multicolumn{1}{|c|}{$N_{\mathrm{e}}$} & \multicolumn{1}{c|}{$P \%$} & $A$ & $A_{\mathrm{e}}$ & $I_{\mathrm{sh}}$ & $H_{\mathrm{o}}$ & $H_{\mathrm{e}}$ & $F$ & $N_{\mathrm{e}} / N$ \\
\hline 1 & 46 & 42.3 & 100.0 & $2.33 \pm 0.33$ & $1.47 \pm 0.19$ & $0.520 \pm 0.145$ & $0.261 \pm 0.055$ & $0.298 \pm 0.081$ & $0.088 \pm 0.105$ & 0.919 \\
2 & 108 & 96.9 & 100.0 & $2.33 \pm 0.33$ & $1.13 \pm 0.05$ & $0.229 \pm 0.068$ & $0.105 \pm 0.04$ & $0.114 \pm 0.041$ & $0.114 \pm 0.108$ & 0.898 \\
3 & 265 & 237.5 & 100.0 & $2.33 \pm 0.33$ & $1.18 \pm 0.08$ & $0.299 \pm 0.109$ & $0.121 \pm 0.035$ & $0.148 \pm 0.057$ & $0.116 \pm 0.09$ & 0.896 \\
4 & 154 & 108.1 & 100.0 & $2.33 \pm 0.33$ & $1.38 \pm 0.18$ & $0.387 \pm 0.166$ & $0.097 \pm 0.075$ & $0.246 \pm 0.114$ & $0.424 \pm 0.271$ & 0.702 \\
5 & 39 & 29.1 & 66.7 & $1.67 \pm 0.33$ & $1.23 \pm 0.19$ & $0.244 \pm 0.169$ & $0.145 \pm 0.109$ & $0.152 \pm 0.117$ & $0.340 \pm 0.331$ & 0.746 \\
6 & 190 & 186.1 & 100.0 & $2.33 \pm 0.33$ & $1.43 \pm 0.19$ & $0.488 \pm 0.149$ & $0.261 \pm 0.063$ & $0.278 \pm 0.087$ & $0.021 \pm 0.066$ & 0.979 \\
7 & 79 & 74.0 & 100.0 & $2.33 \pm 0.33$ & $1.59 \pm 0.16$ & $0.550 \pm 0.071$ & $0.342 \pm 0.092$ & $0.358 \pm 0.072$ & $0.067 \pm 0.11$ & 0.937 \\
8 & 14 & 10.9 & 66.7 & $1.67 \pm 0.33$ & $1.10 \pm 0.05$ & $0.172 \pm 0.086$ & $0.095 \pm 0.048$ & $0.088 \pm 0.044$ & $0.282 \pm 0.359$ & 0.780 \\
9 & 39 & 36.3 & 100.0 & $2.33 \pm 0.33$ & $1.30 \pm 0.20$ & $0.366 \pm 0.191$ & $0.154 \pm 0.068$ & $0.194 \pm 0.111$ & $0.074 \pm 0.122$ & 0.931 \\
10 & 25 & 20.2 & 66.7 & $2.00 \pm 0.58$ & $1.32 \pm 0.17$ & $0.373 \pm 0.199$ & $0.24 \pm 0.122$ & $0.212 \pm 0.11$ & $0.24 \pm 0.381$ & 0.806 \\
11 & 40 & 38.2 & 100.0 & $2.00 \pm 0.00$ & $1.44 \pm 0.08$ & $0.475 \pm 0.051$ & $0.275 \pm 0.038$ & $0.300 \pm 0.043$ & $0.047 \pm 0.166$ & 0.955 \\
\hline
\end{tabular}

$N$, number of analyzed specimens; $N_{\mathrm{e}}$, effective population size; $P \%$, percentage of polymorphic loci; $A$, average number of alleles per locus; $A_{\mathrm{e}}$, effective number of alleles; $I_{\mathrm{sh}}$, Shannon index; $H_{\mathrm{e}}$, expected heterozygosity; $H_{\mathrm{o}}$, observed heterozygosity.

Table 4. Parameters of genetic heterogeneity in populations of $C$. vindobonensis, averaged over set of DNA loci

\begin{tabular}{c|c|c|c|c|c|c|c|c}
\hline \multirow{2}{*}{ Point } & \multirow{2}{*}{$N$} & \multicolumn{2}{|c|}{ Allele frequencies } & \multirow{2}{*}{$P \%$} & $A$ & $A_{\mathrm{e}}$ & $H_{\mathrm{e}}$ & $I_{\text {sh }}$ \\
\cline { 3 - 4 } & & $p$ & $q$ & & & & \\
\hline 1 & 30 & 0.351 & 0.649 & 85.7 & $1.86 \pm 0.06$ & $1.35 \pm 0.05$ & $0.219 \pm 0.029$ & $0.345 \pm 0.04$ \\
2 & 19 & 0.278 & 0.722 & 68.6 & $1.69 \pm 0.08$ & $1.22 \pm 0.05$ & $0.146 \pm 0.026$ & $0.242 \pm 0.038$ \\
3 & 120 & 0.340 & 0.660 & 74.3 & $1.74 \pm 0.07$ & $1.24 \pm 0.05$ & $0.160 \pm 0.028$ & $0.257 \pm 0.041$ \\
4 & 64 & 0.330 & 0.670 & 80.0 & $1.80 \pm 0.07$ & $1.31 \pm 0.06$ & $0.193 \pm 0.03$ & $0.303 \pm 0.043$ \\
5 & 39 & 0.336 & 0.664 & 40.0 & $1.58 \pm 0.01$ & $1.08 \pm 0.01$ & $0.178 \pm 0.005$ & $0.29 \pm 0.007$ \\
6 & 40 & 0.319 & 0.681 & 31.4 & $1.47 \pm 0.002$ & $1.01 \pm 0.002$ & $0.165 \pm 0.001$ & $0.267 \pm 0.001$ \\
7 & 53 & 0.337 & 0.663 & 71.4 & $1.71 \pm 0.08$ & $1.22 \pm 0.05$ & $0.142 \pm 0.028$ & $0.232 \pm 0.04$ \\
8 & 24 & 0.398 & 0.602 & 54.3 & $1.54 \pm 0.08$ & $1.23 \pm 0.05$ & $0.143 \pm 0.03$ & $0.223 \pm 0.044$ \\
9 & 34 & 0.363 & 0.637 & 57.1 & $1.57 \pm 0.08$ & $1.26 \pm 0.06$ & $0.154 \pm 0.032$ & $0.237 \pm 0.046$ \\
10 & 25 & 0.178 & 0.822 & 68.6 & $1.69 \pm 0.08$ & $1.32 \pm 0.06$ & $0.191 \pm 0.033$ & $0.292 \pm 0.047$ \\
11 & 40 & 0.387 & 0.613 & 51.4 & $1.51 \pm 0.09$ & $1.18 \pm 0.05$ & $0.112 \pm 0.028$ & $0.178 \pm 0.041$ \\
\hline \multicolumn{2}{l}{ Mean } & $0.329 \pm 0.018$ & $0.671 \pm 0.018$ & $62.1 \pm 1.5$ & $1.65 \pm 0.06$ & $1.22 \pm 0.04$ & $0.164 \pm 0.024$ & $0.260 \pm 0.035$ \\
\hline
\end{tabular}

model [27] (Table 7), as well as using the analysis of molecular dispersion (AMOVA) [28] (Tables 8, 9). The results of the cluster analysis based on the genetic distances unweighted pair group method (UPGMA) are presented in Fig. 3, and a plot of the correlation between the level of gene flow and geographical distances between groups is shown in Fig. 4.

At the final stage, we estimated the effective number of $C$. vindobonensis populations using different models. The first method of calculation was performed based on the inbreeding coefficient: $N_{\mathrm{e}}=N /(1+F)$ [29]. In order to obtain comparable data, we calculated the ratio of the effective dataset size to its total volume (Table 3 ).

The second calculation method was based on the linear function coefficient between pairwise estimations of the gene flow $\left(N_{m}\right)$ and geographic distance between populations $(D g): \log N_{m}=a+b \log D g$. The effective population size (for all the studied populations in general) was calculated as $N_{\mathrm{e}}=10^{a}$, where $a$ is the coefficient obtained in the equation [30]. The utilized equations are shown in Fig. 4. The obtained results are listed in Table 10.

Another method used by us to calculate the effective size of the populations is based on the model in which the values of the subdivision index of the population are considered [31]:

$$
\begin{gathered}
F_{\mathrm{st}}=\frac{1-t_{k}}{1+t_{k}}, \text { where } t_{k}=\exp -\left\{\left(\frac{1}{N_{\mathrm{e}}}[\ln (K-0.5)\right.\right. \\
+0.5772]+\left(\frac{1}{2 N_{\mathrm{e}}^{2}}\right)\left[1.6449 \frac{2}{2 K-1}\right] \\
\left.+\left(\frac{1}{3 N_{\mathrm{e}}^{3}}\right)\left[1.202 \frac{2}{(2 K-1)^{2}}\right]\right\},
\end{gathered}
$$

RUSSIAN JOURNAL OF GENETICS: APPLIED RESEARCH Vol. $8 \quad$ No. $2 \quad 2018$ 
Table 5. Allozyme genotypes and estimations of potential genetic diversity obtained by different methods for investigated populations of $C$. vindobonensis

\begin{tabular}{c|c|c|c|c|c|c}
\hline \multirow{2}{*}{ Population } & \multirow{2}{*}{$N_{\text {MLG }}$} & \multirow{2}{*}{$N_{\text {MLG-1 }}$} & \multicolumn{4}{|c}{ Method } \\
\cline { 4 - 6 } & & & \multicolumn{2}{|c}{ Chao1-bc } & \multicolumn{2}{c}{ 1st order jackknife } \\
\cline { 4 - 6 } & & & $N_{\max } \pm S E$ & $95 \%$ CI & $N_{\max } \pm S E$ & $95 \%$ CI \\
\hline 1 & 16 & 0 & $22.8 \pm 6.5$ & $17.4-49.1$ & $23.8 \pm 3.9$ & $19.1-35.8$ \\
2 & 9 & 0 & $10.5 \pm 2.6$ & $9.1-24.0$ & $12.0 \pm 2.4$ & $9.7-21.1$ \\
3 & 17 & 0 & $20.3 \pm 4.1$ & $17.5-39.0$ & $22 \pm 3.2$ & $18.6-32.5$ \\
4 & 8 & 1 & $8.5 \pm 1.3$ & $8.0-16.2$ & $10.0 \pm 2.0$ & $8.4-18.2$ \\
5 & 5 & 0 & $5.2 \pm 0.7$ & $5.0-9.6$ & $6.0 \pm 1.4$ & $5.1-12.7$ \\
6 & 20 & 1 & $23.3 \pm 4.1$ & $20.5-42.0$ & $25.0 \pm 3.1$ & $21.6-35.5$ \\
7 & 20 & 5 & $28.9 \pm 7.5$ & $22.1-57.6$ & $29.9 \pm 4.4$ & $24.3-42.9$ \\
8 & 2 & 0 & $2.0 \pm 0.0$ & $2.0-2.0$ & $2.0 \pm 0.0$ & $2.0-2.0$ \\
9 & 9 & 0 & $10.5 \pm 2.5$ & $9.1-23.7$ & $11.9 \pm 2.4$ & $9.7-20.9$ \\
10 & 6 & 0 & $7.0 \pm 2.1$ & $6.1-19.2$ & $7.9 \pm 1.9$ & $6.4-15.9$ \\
11 & 11 & 4 & $12.0 \pm 1.8$ & $1.1-21.5$ & $13.9 \pm 2.4$ & $11.7-23.0$ \\
\hline
\end{tabular}

Table 6. Measures of genetic differentiation and heterogeneity of population of $C$. vindobonensis averaged on set of allozyme loci

\begin{tabular}{l|c|c|c|c}
\hline \multicolumn{1}{c|}{ Parameters } & EST2 & EST3 & EST8 & Mean \\
\hline$H_{\mathrm{e}}$ & 0.192 & 0.183 & 0.277 & 0.217 \\
$H_{\mathrm{o}}$ & 0.184 & 0.186 & 0.202 & 0.191 \\
$F_{\mathrm{is}}$ & 0.040 & -0.014 & 0.271 & 0.099 \\
$F_{\text {it }}$ & 0.123 & 0.299 & 0.487 & 0.303 \\
$F_{\mathrm{st}}$ & 0.087 & 0.309 & 0.297 & 0.231 \\
$N_{m}$ & 2.628 & 0.558 & 0.591 & 0.832 \\
$d f$ & 9 & 9 & 22 & 40 \\
$\chi^{2}$ & 38.4 & 6.0 & 218.9 & 263.3 \\
$P$ & 0.000 & 0.700 & 0.000 & 0.000 \\
\hline
\end{tabular}

$F_{\mathrm{jt}}$, inbreeding coefficient of individual relative to large population; $F_{\mathrm{is}}$, inbreeding coefficient of individual relative to subpopulation $F_{\mathrm{st}}$, inbreeding coefficient of subpopulation relative to large population; $P$, probability of significance of $\chi^{2}$ criterion; $d f$, degrees of freedom.

where $K$ is the number of populations used. Due to the fact that, in order to determine the degree of population subdivision in the present study, we used two integral and interchangable indices $G_{\mathrm{st}}$ and $\Phi_{\mathrm{st}}$, together with the $F_{\text {st }}$ index, we found it possible to modify the indicated formula, introducing the values of these indices into it alternately. The results are given in Table 11.

\section{DISCUSSION}

According to the data obtained on allozymes (Table 2), a significant deficiency of the heterozygotes is observed in $30.3 \%$ of the cases ${ }^{2}$, in the remaining

\footnotetext{
${ }^{2}$ Significance of heterozygote deficiency was estimated according to the formula $\chi^{2}=F^{2} N(k-1), d f=k-1$, where $F$ is the inbreeding coefficient, $N$ is the dataset size, and $k$ is the number of alleles for the given locus [29].
}

versions, significant differences between the observed and theoretical heterozygosity were not found. The data given in Fig. 5, where an insignificant trend towards the scarcity of heterozygotes is present, indicate the same; at the same time, the regression coefficient was $0.958 \pm 0.195(p=0.05)$.

According to the data listed in Table 3, the smallest level of variability and an increased value of the inbreeding coefficient based on the isozyme loci among the six studied populations of the Southern Mid-Russian Upland (points 1-6) are noted in the groups from the points Valuiki (no. 4), Rzhevka (no. 5), and Khotmyzhsk (no. 2). Beyond the borders of the Mid-Russian Upland, the group from Khortitsa Island (no. 8) proved to be the most monomorphic. In the latter case, the low indices of genetic variability are possible due to the isolation and small population of the island group. Natural populations from the points 
Table 7. Parameters of genetic differentiation of populations of $C$. vindobonensis based on DNA loci

\begin{tabular}{|c|c|c|c|c|}
\hline Locus & No & $H_{\mathrm{t}}$ & $H_{\mathrm{s}}$ & $G_{\mathrm{st}}$ \\
\hline OPA1O & $\begin{array}{r}1 \\
2 \\
3 \\
4 \\
5 \\
6 \\
7 \\
8 \\
9 \\
10 \\
11 \\
12 \\
13 \\
14 \\
15 \\
16 \\
17\end{array}$ & $\begin{array}{l}0.163 \\
0.167 \\
0.414 \\
0.123 \\
0.497 \\
0.157 \\
0.221 \\
0.100 \\
0.081 \\
0.197 \\
0.387 \\
0.232 \\
0.037 \\
0.043 \\
0.274 \\
0.424 \\
0.021\end{array}$ & $\begin{array}{l}0.135 \\
0.147 \\
0.247 \\
0.091 \\
0.348 \\
0.141 \\
0.175 \\
0.061 \\
0.064 \\
0.166 \\
0.149 \\
0.152 \\
0.036 \\
0.037 \\
0.140 \\
0.210 \\
0.021\end{array}$ & $\begin{array}{l}0.172 \\
0.118 \\
0.405 \\
0.258 \\
0.300 \\
0.106 \\
0.207 \\
0.395 \\
0.210 \\
0.158 \\
0.616 \\
0.345 \\
0.028 \\
0.149 \\
0.489 \\
0.505 \\
0.035\end{array}$ \\
\hline$S A S 3$ & $\begin{array}{r}1 \\
2 \\
3 \\
4 \\
5 \\
6 \\
7 \\
8 \\
9 \\
10 \\
11 \\
12 \\
13 \\
14 \\
15 \\
16 \\
17 \\
18\end{array}$ & $\begin{array}{l}0.500 \\
0.045 \\
0.212 \\
0.216 \\
0.054 \\
0.362 \\
0.024 \\
0.494 \\
0.015 \\
0.334 \\
0.031 \\
0.405 \\
0.054 \\
0.120 \\
0.371 \\
0.202 \\
0.028 \\
0.006\end{array}$ & $\begin{array}{l}0.376 \\
0.042 \\
0.193 \\
0.203 \\
0.052 \\
0.292 \\
0.023 \\
0.363 \\
0.014 \\
0.269 \\
0.030 \\
0.279 \\
0.048 \\
0.115 \\
0.334 \\
0.165 \\
0.028 \\
0.006\end{array}$ & $\begin{array}{l}0.248 \\
0.053 \\
0.087 \\
0.061 \\
0.043 \\
0.193 \\
0.034 \\
0.266 \\
0.016 \\
0.196 \\
0.031 \\
0.310 \\
0.100 \\
0.043 \\
0.100 \\
0.181 \\
0.022 \\
0.031\end{array}$ \\
\hline Mean & & $0.200 \pm 0.028$ & $0.147 \pm 0.020$ & 0.265 \\
\hline
\end{tabular}

$G_{\mathrm{st}}$, portion of interpopulation genetic diversity in total diversity; $H_{\mathrm{t}}$, expected portion of heterozygotic genotypes in whole population; $H_{\mathrm{s}}$, average value of intrapopulation diversity for all subpopulations.

Golovchino (no. 1) and Kupyansk (no. 6) are the most polymorphic in the eastern part of the distribution range, and in the western part, the population from the point Zhitomir (no. 7). Fairly high indices of genetic variability also characterize the adventive colony from the city of Penza (no. 11). The analysis of the multilocus variability of allozymes in many respects confirmed these conclusions (Table 5). The greatest observed and potential genetic diversity is noted at points $1,3,6$, and 7 . The greatest number of unique 
Table 8. Result of AMOVA of populations of C. vindobonensis

\begin{tabular}{c|l|r|r|r|r|r|r|r|c}
\hline Markers & \multicolumn{1}{|c|}{ Variability } & \multicolumn{1}{c|}{$d f$} & \multicolumn{1}{c|}{$S S$} & \multicolumn{1}{c|}{$M S$} & $V$ & $\%$ & $\Phi_{\mathrm{st}}$ & $P$ & $N_{m}$ \\
\hline \multirow{3}{*}{ Allozymes } & Between populations & 10 & 241.052 & 24.105 & 0.277 & 26 & & & \\
& Within populations & 988 & 767.090 & 0.776 & 0.776 & 74 & 0.263 & 0.010 & 0.676 \\
& Total & 998 & 1008.142 & 24.882 & 1.053 & - & & & \\
\hline \multirow{3}{*}{ DNA } & Between populations & 10 & 401.573 & 40.157 & 0.882 & 26 & & & \\
& Within populations & 477 & 1187.796 & 2.490 & 2.490 & 74 & 0.261 & 0.010 & 0.630 \\
& Total & 487 & 1589.369 & 42.647 & 3.372 & - & & & \\
\hline
\end{tabular}

Table 9. Pairwise genetic differentiation $\left(\Phi_{\mathrm{st}}\right)$ between populations of $C$. vindobonensis based on allozyme loci and DNA markers

\begin{tabular}{c|c|c|c|c|c|c|c|c|c|c|c}
\hline \multicolumn{10}{c}{ Allozymes } \\
\hline Point & 1 & 2 & 3 & 4 & 5 & 6 & 7 & 8 & 9 & 10 & 11 \\
\hline 1 & & 0.010 & 0.010 & 0.030 & 0.010 & 0.410 & 0.010 & 0.010 & 0.260 & 0.090 & 0.010 \\
2 & 0.124 & & 0.020 & 0.010 & 0.010 & 0.010 & 0.010 & 0.170 & 0.010 & 0.010 & 0.010 \\
3 & 0.076 & 0.021 & & 0.010 & 0.010 & 0.010 & 0.010 & 0.110 & 0.020 & 0.010 & 0.010 \\
4 & 0.050 & 0.129 & 0.119 & & 0.010 & 0.010 & 0.010 & 0.030 & 0.010 & 0.010 & 0.010 \\
5 & 0.546 & 0.708 & 0.665 & 0.542 & & 0.010 & 0.010 & 0.010 & 0.010 & 0.010 & 0.010 \\
6 & 0.000 & 0.090 & 0.072 & 0.049 & 0.549 & & 0.010 & 0.010 & 0.260 & 0.040 & 0.010 \\
7 & 0.136 & 0.296 & 0.297 & 0.146 & 0.360 & 0.175 & & 0.030 & 0.010 & 0.010 & 0.010 \\
8 & 0.106 & 0.032 & 0.028 & 0.099 & 0.673 & 0.112 & 0.177 & & 0.030 & 0.010 & 0.010 \\
9 & 0.008 & 0.062 & 0.025 & 0.063 & 0.649 & 0.008 & 0.230 & 0.110 & & 0.040 & 0.010 \\
10 & 0.030 & 0.084 & 0.070 & 0.134 & 0.587 & 0.042 & 0.188 & 0.135 & 0.036 & & 0.010 \\
11 & 0.463 & 0.729 & 0.683 & 0.513 & 0.765 & 0.513 & 0.567 & 0.667 & 0.544 & 0.571 & \\
\hline & & & & & & & & \\
1
\end{tabular}

Estimations of $\Phi_{\mathrm{st}}$ are listed under diagonal; level of their significance (based on 99 permutations) are listed above diagonal.

genotypes ( $\left.N_{\mathrm{MLG}-1}\right)$ is also noted at points 7 and 11 . The group from Khortitsa Island (no. 8) proved to be the most uniform.

Judging by the indices of genetic heterogeneity averaged based on the combination of DNA loci (Table 5), the populations Rzhevka (no. 5) and Kupyansk (no. 6) were the most monomorphic. This result is natural for the fifth group, since a reduction in the allelic diversity here was also observed based for the isozyme markers ${ }^{3}$. However, the sixth group dif-

\footnotetext{
${ }^{3}$ This phenomenon is possibly determined by the population waves due to the burning of dry vegetation during the spring period observed at this point; as a result, individuals in their active phase die.
} 
(a)

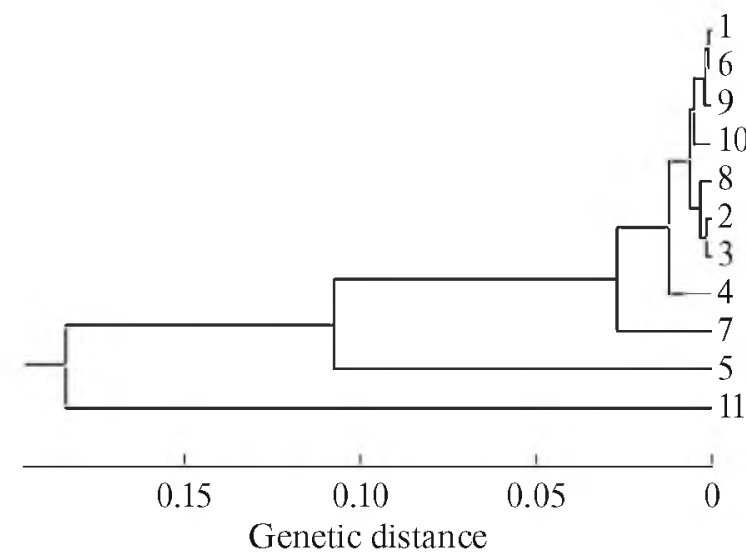

(b)

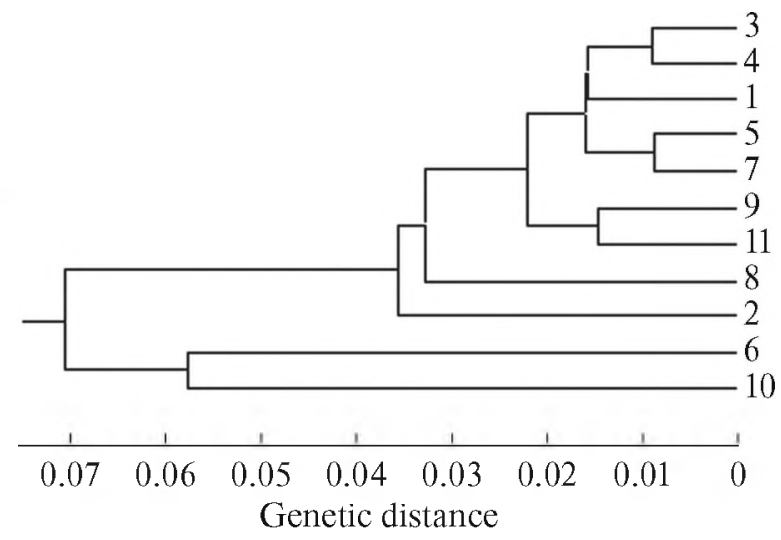

Fig. 3. Dendrogram of genetic distances by Nei [33] (UPGMA) between populations of $C$. vindobonensis based on allozyme loci (a) and DNA markers (b).

(a)

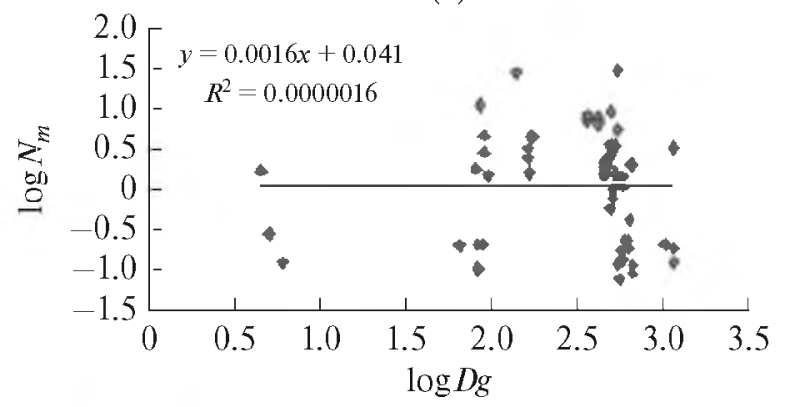

(b)

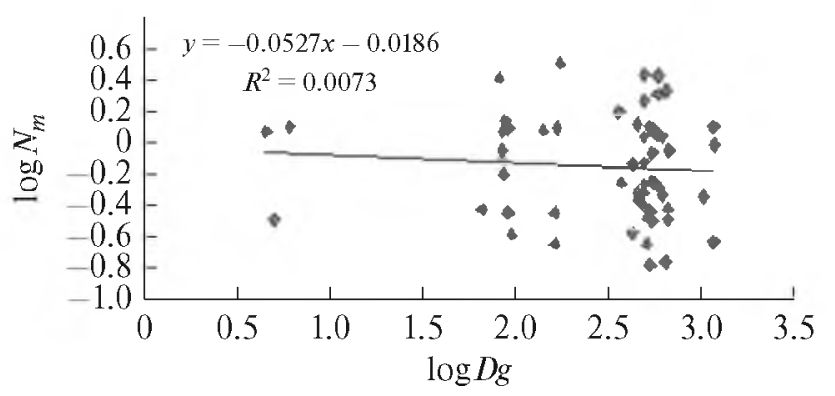

Fig. 4. Linear regression logarithm of gene flow $N_{m}$ between population pairs of $C$. vindobonensis on logarithm geographic distance $D g$ between them ((a) for allozymes; (b) for DNA markers).

fered in terms of the increased variability based on allozymes. From the populations outside the borders of the Mid-Russian Upland, the adventive population from the city of Penza (no. 11) proved to be the most monomorphic. The obtained result appears somewhat unexpected, since this group is separated from the rest by the larger heterogeneity based on the allozymes. Furthermore, according to the data obtained earlier, this colony differed by the high diversity of the color variants of the shell [15]. In this respect, we assume that this case once again demonstrates the difference in genetic processes which take place in the coding part of the genome subjected to natural selection and which comply with the genetically automatic laws in the remaining part of the "silent" DNA. Earlier we already attempted to explain the significant morphological variability of this colony by the special microclimatic conditions of the urban environment, as well as by the competitive vacuum and the absence of predators [15]. In the line of this reasoning, an increased monomorphism revealed based on the DNA markers is a possible result of the genetic drift caused by the "founder effect."
Regarding individual DNA loci, loci 3, 5, and 16 were the most polymorphous among the $R A P D$ markers, and loci 1,8 , and 15 were more variable among the ISSR markers (Table 7). Loci 8, 9, 13, 14, and 17 were included in the group of more monomorphic loci based on the OPA10 primer, and loci 2, 5, 7, 9, 11, 13, 17 , and 18 were included based on the $S A S 3$ primer. It is interesting to note that on average the heterozygosity of the $R A P D$ loci $\left(H_{\mathrm{t}}=0.208 \pm 0.035, H_{\mathrm{s}}=0.136 \pm 0.020\right)$ does not significantly differ from the heterozygosity of the ISSR loci $\left(H_{\mathrm{t}}=0.192 \pm 0.041, H_{\mathrm{s}}=0.157 \pm 0.031\right)$.

In general, it is interesting to note that the level of variability of the $C$. vindobonensis populations in the Southern Mid-Russian Upland is not inferior, and in certain cases exceeds the analogous level of variability in the western groups, which we assume is a positive signal as an estimation of the viability of the species' populations.

Estimation of the degree of differentiation of populations based on the allozyme loci with the use of $F$-statistics of S. Wright on the average demonstrated a sufficiently large dissociation of the studied groups of 
Table 10. Values of effective size calculated based on linear function coefficients between pairwise estimates of gene flow $\left(N_{m}\right)$ and geographic distances between populations of different species of terrestrial mollusks

\begin{tabular}{l|c|c|c|c}
\hline \multirow{2}{*}{\multicolumn{1}{c|}{ Species }} & \multicolumn{2}{|c|}{ Isozymes } & \multicolumn{2}{c}{ DNA } \\
\cline { 2 - 5 } & $N_{\mathrm{e}}$ & $95 \%, \Delta$ & $N_{\mathrm{e}}$ & $95 \%, \Delta$ \\
\hline Helix pomatia & 9.8 & $3.9-25.1$ & 3.1 & 1.7 \\
Bradybaena fruticum & 4.1 & $2.2-7.6$ & 1.2 & $1.2-2.5$ \\
Chondrula tridens & 3.8 & $2.6-5.7$ & 1.9 & $0.8-1.8$ \\
Helicopsis striata & 5.1 & $2.6-10.0$ & 0.96 & $1.3-2.7$ \\
Cepaea vindobonensis & 1.1 & $0.14-8.5$ & $0.36-2.6$ & \\
\hline
\end{tabular}

Data on Br. fruticum, Ch. tridens, $H$. striata, and $H$. pomatia were obtained from our previous publications [38-44]. Same for Table 11.

Table 11. Values of effective size of populations of different species, calculated based on subdivision index $\left(F_{\mathrm{st}}, G_{\mathrm{st}}\right.$, and $\left.\Phi_{\mathrm{st}}\right)$

\begin{tabular}{l|c|c|c|c|c}
\hline \multicolumn{1}{c|}{ Index } & $\begin{array}{c}\text { Br. fruticum } \\
(K=35)\end{array}$ & $\begin{array}{c}\text { Ch. tridens } \\
(K=25)\end{array}$ & $\begin{array}{c}\text { H. striata } \\
(K=19)\end{array}$ & $\begin{array}{c}\text { H. pomatia } \\
(K=12)\end{array}$ & $\begin{array}{c}C \text {. vindobonensis } \\
(K=11)\end{array}$ \\
\hline$N_{\mathrm{e}}\left(F_{\mathrm{st}}\right.$ based on allozymes $)$ & 9.2 & 10.5 & 4.9 & 5.3 & 6.0 \\
$N_{\mathrm{e}}\left(\Phi_{\mathrm{st}}\right.$ based on allozymes $)$ & 7.0 & 6.2 & 3.5 & 3.1 & 6.1 \\
$N_{\mathrm{e}}\left(G_{\mathrm{st}}\right.$ based on DNA) & 7.3 & 10.3 & 4.9 & 5.9 & 6.6 \\
$N_{\mathrm{e}}\left(\Phi_{\mathrm{st}}\right.$ based on DNA) & 6.2 & 9.9 & 4.4 & 3.8 & 6.3 \\
Mean & $7.4 \pm 0.6$ & $9.2 \pm 1.0$ & $4.4 \pm 0.3$ & $4.5 \pm 0.6$ & $6.3 \pm 0.1$ \\
\hline
\end{tabular}

snails (Table 6). We observe a similar picture while comparing the data obtained based on the analysis of the molecular variance (AMOVA, Table 8). In both cases, the index of the intensity of the exchange of genes between populations $\left(N_{m}\right)$ proved to be less than one, which, according to the "shifting balance theory," disrupts panmixia between the populations [31]. The relatively high values of the inbreeding coefficient $F_{\text {it }}$ also indicate the same. Note that the EST3 locus makes the greatest contribution to the interpopulation diversity, evaluated based on the inbreeding coefficient $F_{\text {st }}$ (Table 6). However, the heterogeneity test using the $\chi^{2}$ criterion did not reveal a significant separation of the groups based on this locus $(p=0.7)$.

Based on the utilized DNA markers, the greatest fragmentation is noted for loci nos. 11, 15, and 16 $(O P A 10)$, and nos. 1, 8, 10, and 12 (SAS3) (Table 7). It

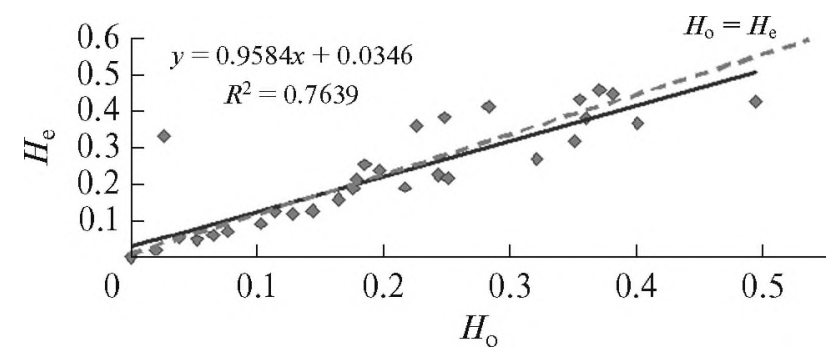

Fig. 5. Ratio of expected $\left(H_{\mathrm{e}}\right)$ and observed heterozygosity $\left(H_{\mathrm{O}}\right)$ in populations of $C$. vindobonensis. is known that the average $G_{\text {st }}$ values correspond to the level of genetic differentiation with the neutral selective process. In that case, loci with large $G_{\text {st }}$ values can most probably experience the action of disruptive selection, and loci with low values of the subdivision index are subjected to the influence of stabilizing selection [32]. The differences based on the RAPD spectra $\left(G_{\mathrm{st}}=0.264\right)$ proved to be higher than those for the $I S S R$ spectra $\left(G_{\mathrm{st}}=0.112\right)$.

The analysis of molecular dispersion both for allozymes and DNA markers demonstrated a similar picture. In either case, the intrapopulation variability contributed to $26 \%$, and the $\Phi_{\mathrm{st}}$ subdivision indices of the populations insignificantly differed from the $F_{\mathrm{st}}$ and $G_{\mathrm{st}}$ indices. Accordingly, the level of the gene flow $\left(N_{m}\right)$ was $0.630-0.676$ individuals per generation (Table 8).

The results of the cluster analysis demonstrated an explicit difference in the divergence of groups into clusters between the dendrograms reconstructed based on the allozyme and DNA markers (Fig. 3). At the same time, in both cases the geographical location of the populations does not have any effect on the similarity in the ratio of allele frequencies and their combinations. For example, the adjacent populations that inhabit the valley of Vorskla River (points 1,2), despite close three-dimensional arrangement, proved to be, according to the diagrams, in different clusters. The differentiation level between them was $\Phi_{\mathrm{st}}=0.124$ based on allozymes, and $F_{\text {st }}=0.174(p=0.01)$ based on 
DNA markers (Table 9). It is interesting to note that anthropogenic pressure could contribute to this originality. The Khotmyzhsk group (no. 2) inhabits the floodland sections plowed previously, which were neglected by man for more than 30 years. The development of this territory probably occurred from the preserved natural islets of the floodland vegetation, in which small groups of snails remained. The group experienced the so-called bottleneck effect and possibly the genetic revolution effect [34] and became more monomorphic than the Golovchino population (no. 1), which inhabited a natural forest biotope. This possibly indicates the tendency of the species towards the formation of a metapopulation structure under the conditions of the urbanized territory of the Southern Mid-Russian Upland [35].

The most original group regarding the genetic combinations of the isozyme markers is the colony from the city of Penza (no. 11). Specifically, a high frequency of the EST8-1 allele (0.763) is found here. Its portion does not exceed 0.141 in all other populations. This phenomenon can be considered either a consequence of the genetic drift because of the founder principle or a result of natural selection in the urban environment.

The Kupyansk (no. 6) and STP groups from the city of Nikolayev (no. 10) are the most distanced based on the DNA markers. Moreover, the latter population differs significantly not only from the remote groups but also from the adjacent group, which inhabits the same city (no. 9). The level of differentiation between them reached $\Phi_{\mathrm{st}}=0.436(p=0.01)$ (Table 9), which indicates a significant isolation of the snail colonies in an urbanized environment. It should be noted that the data obtained are partially inconsistent with the assumption of S.S. Kramarenko [14], according to which the studied group of $C$. vindobonensis in urban conditions exists as many discrete semi-isolated colonies that meet Wright's island model.

The cluster analysis data are confirmed by the graphs and equations of linear regression (Fig. 4), which demonstrate the absence of a correlation between the geographical distances and pairwise estimations of the gene flow both according to the allozymes (Mantel test $R_{\mathrm{M}}=0.001, p=0.518,9999$ permutations) and according to the DNA markers ( $R_{\mathrm{M}}=$ $-0.085, p=0.315,9999$ permutations). All this speaks about the disturbance of the migratory channels between the studied groups of $C$. vindobonensis and their prolonged isolation from each other.

The calculation of the effective size of $C$. vindobonensis populations using the inbreeding coefficient demonstrated that the ratio of the effective size to the total size of the population $\left(N_{\mathrm{e}} / N\right)$ for the species in general is $0.868 \pm 0.028$ (Table 3 ), which fits within the overall range of the share of $N_{\mathrm{e}}$ proposed by Crow et al. $[36,37]^{4}$. Furthermore, the average value of the

\footnotetext{
${ }^{4}$ The authors determined that for the majority of the organisms the portion of $N_{\mathrm{e}}$ is 0.75 on average.
}

portion of $N_{\mathrm{e}}$ obtained for $C$. vindobonensis significantly exceeds the analogous values obtained by us earlier for the aboriginal background species of terrestrial mollusks that inhabit the studied region: Br. fruticum: $0.800 \pm 0.021$ and Ch. tridens: $0.661 \pm 0.013$ [38, 39 ], as well as for the relict mollusk Helicopsis striata: $0.720 \pm 0.080[39,40]$. The portion of the effective population size of $C$. vindobonensis proved comparable to the Roman snail Helix pomatia inhabiting this location that has a high life potential: $0.870 \pm 0.043$ [41]. These data indirectly indicate a high level of viability for the studied populations of $C$. vindobonensis.

Comparison of the obtained estimations of the effective size of the $C$. vindobonensis populations, calculated based on the equation of linear regression with the analogous data on other species of mollusks demonstrates an explicit decrease of this index for the groups of this land snail (Table 10), although the calculated confidence intervals show that significant differences are absent.

We obtained a somewhat different result during the calculation of the effective population size while taking into account the level of the subdivision of the populations (Table 11). According to the obtained data, Ch. tridens and Br. fruticum have the largest effective population size. In the $C$. vindobonensis populations, the effective size was lower than in these two background species, and higher than in the $H$. striata and $H$. pomatia, which are considered vulnerable mollusks.

\section{CONCLUSIONS}

Thus, based on the given data it can be established in general that from the point of view of genetic parameters in comparison with, for example, the vulnerable species $H$. striata, which often inhabits the same communities as $C$. vindobonensis, the studied populations of the latter have higher life opportunities. This is determined partially by the fact that $C$. vindobonensis is an euritopic species. Populations of these snails can inhabit open steppificated slopes, forest communities, and sections adjacent to floodlands due to their polymorphism. The cases of the successful development of gardens and orchards by the mollusks were noted. Nevertheless, reduction in the allelic diversity, an increase in the inbreeding coefficient in a number of groups, and the high level of isolation of C. vindobonensis populations in the northeastern part of the distribution range raises concerns and requires efforts to be made to preserve this species.

\section{ACKNOWLEDGMENTS}

We thank T.G. Stoiko and S.S. Kramarenko for the material provided for the analysis. 


\section{REFERENCES}

1. Shileiko, A.A., Terrestrial mollusks of the superfamily Helicoidea, in Fauna SSSR. Mollyuski (Fauna of the USSR. Mollusks), Leningrad: Nauka, 1978, vol. 4, no. 6.

2. Snegin, E.A., Application of species of terrestrial mollusks as indicators of relict cenoses, Vestn. Zhitomir. Pedagog. Univ., 2002, no. 10, pp. 128-129.

3. Krasnaya kniga Belgorodskoi oblasti. Redkie i ischezayushchie rasteniya, griby, lishainiki i zhivotnye (The Red Data Book of the Belgorod Region. Rare and Endangered Plants, Fungi, Lichens, and Animals), Belgorod, 2004.

4. Rotarides, M., Über die Bändervariationen von Cepaea vindobonensis Fér, Zool. Anz., 1926, vol. 67, nos. 1-2, pp. 28-44.

5. Jones, J.S., Environmental selection in the snail Cepaea vindpbonensis in the Lika area of Yugoslavia, Heredity, 1974, vol. 32, no. 2, pp. 165-170. doi 10.1038/ hdy. 1974.20

6. Jones, J.S., The genetic structure of some steppe populations of the snail Cepaea vindobonensis, Genetica, 1975, vol. 45, pp. 217-225. doi 10.1038/hdy.1974.20

7. Sacchi, C.F., Population ecology of Cepaea nemoralis and $C$. vindobonensis along the north Adriatic coasts of Italy, Malacologia, 1984, vol. 25, no. 2, pp. 315-323.

8. Khlus, L.M. and Khlus, K.M., Conchological characteristics of Bukovina populations of Cepaea vindobonensis Fer. (Geophyla, Helicidae), Materiali konf. "Gori i lyudi (u konteksti stalogo razvitku)" (Proc. Conf. Mountains and People (in the Context of Sustainable Development)), Rakhiv, 2002, vol. 2, pp. 522-526.

9. Honek, A., Shell-band color polymorphism in Cepaea vindobonensis at the northern limit of its range, Malacologia, 2003, vol. 25, pp. 133-140.

10. Sverlova, N.V. and Kirpan, S.P., The phenotypic structure of Cepaea vindobonensis (Gastropoda, Pulmonata, Helicidae) populations in Western Ukraine, Nauk. Zap. Derzh. Prirodozn. Muz., 2004, vol. 19, pp. 107-114.

11. Gural'-Sverlova, N.V. and Martynov, V.V., Conchological features of Cepaea vindobonensis populations in the Donetsk oblast, Probl. Ekol. Okhr. Prir. Tekhnog. Reg., 2007, no. 7, pp. 85-91.

12. Kramarenko, S.S., Khokhutkin, I.M., and Grebennikov, M.E., Specific features of phenetic structure of the terrestrial snail Cepaea vindobonensis (Pulmonata; Helicidae) in urbanized and natural populations, Russ. J. Ecol., 2007, vol. 38, no. 1, pp. 39-45. doi $10.1134 / \mathrm{S} 1067413607010079$

13. Ożgo, M. and Komorowska, A., Shell banding polymorphism in Cepaea vindobonensis in relation to habitat in southeastern Poland, Malacologia, 2009, vol. 51, no. 1, pp. 81-88. doi 10.4002/040.051.0105

14. Kramarenko, S.S., Analysis of the genetic structure of the populations of terrestrial mollusk Cepaea vindobonensis (Gastropoda, Pulmonata, Helicidae) populations using the RAPD marker, Vestn. Zool., 2009, vol. 43, no. 5, pp. 449-455.

15. Snegin, E.A., Vitality estimation of the Cepaea vindobonensis (Mollusca, Gastropoda, Pulmonata) especially protected species populations in the conditions of the Central Russian Upland forest-steppe south, Vestn.
Krasnoyarsk. Gos. Agrar. Univ., 2011, no. 11, pp. 142148.

16. Neiber, M.T. and Hausdorf, B., Molecular phylogeny reveals the polyphyly of the snail genus Cepaea (Gastropoda: Helicidae), Mol. Phyl. Evol., 2015, vol. 93, pp. 143-149. doi 10.1016/j.ympev.2015.07.022

17. Neiber, M.T., Sagorny, C., and Hausdorf, B., Increasing the number of molecular markers resolves the phylogenetic relationship of 'Cepaea' vindobonensis (Pfeiffer 1828) with Caucasotachea Boettger 1909 (Gastropoda: Pulmonata: Helicidae), J. Zool. Syst. Evol. Res., 2016, vol. 54, no. 1, pp. 40-45. doi 10.1111/jzs.12116

18. Welsh, J. and McClelland, M., Fingerprinting genomes using CR with arbitrary primers, Nucleic Acids Res., 1990, vol. 18 , no. 22, pp. 7213-7219. 1093/nar/18.24.7213

19. Zietkiewicz, E., Rafalski, A., and Labuda, D., Genome fingerprinting by simple sequence repeat (SSR) anchored polymerase chain reaction amplification, Genomics, 1994, vol. 20, no. 2, pp. 176-181. doi 10.1006/geno.1994.1151

20. Peakall, R. and Smouse, P.E., GenAlEx 6: genetic analysis in Excel. Population genetic software for teaching and research, Mol. Ecol. Notes, 2006, no. 6, pp. 288-295.

21. Yeh, F.C., Yang, R., Boyle, T.J., et al., POPGENE32, Microsoft Window-based Freeware for Population Genetic Analysis, Version 1.32, Edmonton, Canada: Molecular Biology and Biotechnology Centre, University of Alberta, 2000. http://www.ualberta.ca/ fyeh/popgene_download.html.

22. Tamura, K., Stecher, G., Peterson, D., et al., MEGA6: Molecular Evolutionary Genetics Analysis version 6.0, Mol. Phyl. Evol., 2013, vol. 30, pp. 2725-2729. doi $10.1093 / \mathrm{molbev} / \mathrm{mst} 197$

23. Chao, A., Species richness estimation, in Encyclopedia of Statistical Science, Balakrishnan, N., Read, C.B., Vidakovic, B., Eds., New York: Wiley, 2005, pp. 79077916.

24. Burnham, K.P. and Overton, W.S., Estimation of the size of a closed population when capture probabilities vary among animals, Biometrika, 1978, no. 65 , pp. 625-633. doi 10.1093/biomet/65.3.625

25. Chao, A. and Shen, T.-J., SPADE, 2009. http://chao. stat.nthu.edu.tw.

26. Right, S., The genetical structure of populations, Ann. Eugen., 1951, no. 15, pp. 323-354.

27. Nei, M., Molecular Population Genetics and Evolution, Amsterdam, 1975.

28. Excoffier, L., Smouse, P.E., and Quattro, J.M., Analysis of molecular variance inferred from metric distances among DNA haplotypes: Application to human mitochondrial DNA restriction data, Genetics, 1992, no. 131, pp. 479-491.

29. Li, C., First Course in Population Genetics, Pacific Grove, California: The Boxwood Press, 1976.

30. Slatkin, M., Isolation by distance in equilibrium and non-equilibrium populations, Evolution, 1993, vol. 47, no. 1, pp. 294-279. doi 10.2307/2410134

31. Wright, S., Random drift and shifting balance theory of evolution, in Mathematical Topics in Population Genetics, Berlin: Springer Verlag, 1970. doi 10.1007/978-3642-46244-3_1 
32. Dinamika populyatsionnykh genofondov pri antropogennykh vozdeystviyakh (The Dynamics of Population Gene Pools under Anthropogenic Impacts), Altukhov, Yu.P., Ed., Moscow: Nauka, 2004.

33. Nei, M., Genetic distance between populations, Am. Nat., 1972 , vol. 106 , no. 949 , pp. 283-292. doi $10.1086 / 282771$

34. Mayr, E., Animal Species and Evolution, London: Oxford University Press, 1965.

35. Hanski, I., Metapopulation Ecology, Oxford: Oxford University Press, 1999.

36. Crow, J.F. and Morton, N.E., Measurement of gene frequency drift in small population, Evolution, 1955, vol. 9, pp. 202-214. doi $10.2307 / 2405589$

37. Crow, J.F. and Kimura, M., An Introdution to Population Genetics Theory, New York: Harpers and Row, 1970.

38. Snegin, E.A., The genetic structure of model species populations of terrestrial mollusks in conditions of urbanized landscape using the example of Chondrula tridens Müll (Gastropoda, Pulmonata), Russ. J. Genet.: Appl. Res., 2012, vol. 9, no. 2, pp. 160-170. doi 10.1134/S2079059712020128

39. Snegin, E.A., Spatial and temporal aspects of the ecological and genetic structure of populations of invertebrates (on the example of terrestrial mollusks and insects of the south of the Central Russian Upland), Doctoral (Biol.) Dissertation, Belgorod: Belgorod State University, 2012.
40. Snegin, E.A. and Sychev, A.A., Viability estimation of populations of the specially protected species Helicopsis striata Müller (Mollusca, Gastropoda, Pulmonata) in the south of the Central Russian Upland, Teor: Prikl. Ekol., 2011, no. 2, pp. 84-93.

41. Snegin, E.A. and Artemchuk, O.Yu., Morphogenetic analysis of Helix pomatia L. (Pulmonata, Helicidae) populations from southeastern and eastern parts of the modern area, Russ. J. Genet.: Appl. Res., 2016, vol. 6, no. 2, pp. 152-162. doi 10.1134/S207905971602012X

42. Snegin, E.A., Assessment of the state of population gene pools of terrestrial mollusks in conditions of influence of ore dressing combines from the example of Bradybaena fruticum Müll. (Gastropoda, Pullmonata), Russ. J. Genet.: Appl. Res., 2011, vol. 1, no. 5, pp. 379389. doi $10.1134 /$ S2079059711050133

43. Snegin, E.A., Analysis of genetic variability in populations of a terrestrial snail Chondrula tridens Müll. (Gastropoda, Pulmonata), based on the RAPD and ISSR markers, Russ. J. Genet.: Appl. Res., 2014, vol. 4, no. 5 , pp. 444-454. doi 10.1134/S207905971405013X

44. Snegin, E.A., Estimating the state of population gene pools of the specially protected Helicopsis striata (Mollusca, Gastropoda, Pulmonata) species based on DNA markers, Russ. J. Genet.: Appl. Res., 2017, vol. 7, no. 2, pp. 135-144. https://doi.org/10.1134/S2079059717020113.

Translated by A. Lisenkova 